\title{
FORMATION OF YOUNGER PUPILS' SUSTAINABLE INTEREST TO TAKE PHYSICAL CULTURE IN OUTDOOR EDUCATION INSTITUTIONS
}

\author{
Halyna Bilavych \\ Vasyl Stefanyk Precarpathian National University, Ukraine \\ Borys Savchuk \\ Vasyl Stefanyk Precarpathian National University, Ukraine \\ Ivan Bilavych \\ Warsaw Medical University, Poland \\ Mykola Pantiuk \\ Drohobych State Pedagogical University named after Ivan Franko, Ukraine \\ Zoriana Khalo \\ Drohobych State Pedagogical University named after Ivan Franko, Ukraine
}

\begin{abstract}
The results of the study and the data of Ukrainian and foreign scientists showed that children are passively involved in physical activity. School lessons of physical culture lose their priority among the preferences of students. The interests of younger students in physical education contradict with the curriculum. Physical development has a declarative and situational nature, since only about $20 \%$ of children engage in motor activity in the morning. In view of this, the author developed a method of forming a sustainable interest in physical education and sports during the extracurricular institution, which has been introduced from 2017 to the present at the University of Gifted Child (UGC), which operates at the Vasyl Stefanyk Precarpathian National University (Ukraine). Here, they have created a special educational, development and leisure environment of health-conscious content. The study confirmed the hypothesis that the effectiveness of this process is provided by a number of conditions: students have knowledge of physical culture and sports, health, well-known fellow countrymen; practical activity of children; valuable attitude of younger students to physical education, motivation for healthy lifestyle, emotional satisfaction from exercise, physical activity, sports, active rest; highly professional teaching staff who are well-known athletes, creative students; innovative methods and forms of learning, etc. It is proved that if significant attention is paid to the cognitive and value components, then it is possible to generate more intense interest in physical culture in children.
\end{abstract}

Keywords: health care environment, junior high school students, physical activity, physical education lessons, sports, sustained interest in physical culture, University of Gifted Child. 
Bilavych et al., 2020. Formation of Younger Pupils' Sustainable Interest to Take Physical Culture in Outdoor Education Institutions

\section{Introduction}

It is known that physical education and sports have a positive impact on the development of the child, they are especially needed for the modern pupil who spends most of the day sitting at his desk at school and doing homework at home. Children spend a lot of time in front of the TV, a computer that does not promote either physical, moral or spiritual health. According to educators, scientists (Babiuk, 2015; Bezverkhnia, 2003; Vilchkovskyi \& Kurok, 2008; Kravchuk \& Voinarovska, 2017; Krutsevych, Vorobiov, \& Bezverkhnia, 2011), as well as our observations, junior high school students are mostly not interested in sports and physical education, they are not interested in physical activity. In recent years, the volume of educational load of pupils in secondary schools has grown to such a degree that immobility caused by this, the limitations of muscular effort are causing diseases of various body systems (Bergier, Bergier, \& Tsos, 2016; Bezverkhnia, 2003; Iedynak, Galamandjuk, Kyselytsia, Nakonechnyi, Hakman, \& Chopik, 2017).

Let us emphasize: this problem is at the center of attention and the global community. Scientists, educators, the public abroad are alarmed: children and adolescents are increasingly distancing themselves from physical education, and their physical activity is reduced to catastrophic norms. According to UK Sports Secretary Mims Davis, "every third child in England is not physically active enough: children receive less than 30 minutes of exercise per day - half the amount recommended by government recommendations," according to the British Broadcasting Company (BBC). The UK faces serious challenges to increase interest in youth sports - according to an annual report (2017-2018) from a departmental government body at the Department of Digital Culture, Media and Sports, Sport Englang (The challenge of growing youth participation in sport, 2018). These and other sources summarize: "the situation must be changed.” Among the reasons for the loss of interest in physical education and sports - the decline of sustained interest in physical education, the loss of educational orientation of physical education, the lack of innovative methods and forms of working with children, the lack of motivation for physical education, etc. The importance of physical training of younger students is discussed in the research by T. Krutsevych, M. Vorobyov, G. Bezverhnia (Krutsevych, Vorobiov, \& Bezverkhnia, 2011). Works of S. Babiuk (Babiuk, 2015), G. Bezverkhnia (Bezverkhnia, 2003), Ya. Kravchuk, N. Voinarovska (Kravchuk \& Voinarovska, 2017) are devoted to the study of motivation of physical education of pupils of separate classes. However, the problem of formation of younger pupils' sustainable interest has not got much attention from scientists. 
The works of Chen A. \& Darst P.W. (Chen \& Darst, 2001; Chen, Darst, \& Pangrazi, 1999), are devoted to the issue of Situational interest, validating a construct in physical education. The authors state that situational interest is the appealing effect of unique characteristics students recognize in a learning task during interaction with the task.

The purpose of the article is to analyze the use of unconventional technologies in the formation of a strong interest in physical education and sports in out-of-school educational institutions among younger students.

\section{Methodology}

Analysis of scientific and methodological literature, questionnaires, pedagogical experiment were used the following methods to achieve this goal. The study was conducted during 2017-2019 years.

It was preceded by the development of scientific and methodological literature, the development of a complex of theoretical methodological material on the formation of a sustainable interest in the younger students to exercise in physical culture and sports. During the main pedagogical experiment, the effectiveness of the proposed method was determined.

The analysis of literary sources made it possible to determine the state of study of the problem under study in pedagogy, the theory of physical education.

The observation method was used to determine the state of interest of students in physical education and sports, their motor activity. Comparing the observation data with the survey data, reliable information was obtained on the degree of manifestation of their interest in physical education and sports, motor activity.

The questioning process involved the development of a questionnaire for students in 4th grade. Eighty four people took part in it: fourty two boys and fourty two girls from Ivano-Frankivsk city. The questionnaire included a number of questions, including: "How do you spend your free time?", "Do you do exercise in the morning?", "Do you do sports in the afternoons?", "How do you feel about physical education as a subject?”, “Are you satisfied with the physical education lessons at your school?", "Which sections of the physical education curriculum are interesting to you?”.

Statistical data were used to process and analyze the results of the survey. The above scientific methods have been able to identify the factors that influence the formation of motivation for physical education and sports, to identify incentives that promote its development, to develop a method of forming a strong interest in physical education and sports in extracurricular 
Bilavych et al., 2020. Formation of Younger Pupils' Sustainable Interest to Take Physical Culture in Outdoor Education Institutions

institutions through the creation of appropriate environment within the Vasyl Stefanyk Precarpathian National University, outline specific recommendations for physical education teachers.

\section{Research results}

The results of the research of scientists, as well as our observations on the educational process in the schools of Ivano-Frankivsk city and the Vasyl Stefanyk Precarpathian National University (Ukraine) confirm the thesis that, unfortunately, the level of interest of children / students in physical education and sports decreases. In the upper grades of the school, and therefore in the university, it is almost extinct. And only some persons like physical education and sports. The results of a survey of 4 th grade students in Ivano-Frankivsk city (84 people, 42 boys and 42 girls) showed that almost $80 \%$ of younger students are passive about their own physical activity, physical education, leisure is usually spent on computer games, watching cartoons, communicating on social networks, "in front of the TV"; only $20 \%$ of boys participate in sports sections in the afternoons, $22 \%$ of girls engage in dancing. More than $90 \%$ of children do no do physical exercises in the morning, $75 \%$ of the respondents admitted that they exercise "inactivity" because it is "uninteresting", "monotonous"; only $26 \%$ of students indicated that they systematically play outdoors, run, play football and other games after school. Only $62 \%$ of boys and $33 \%$ of girls said that physical education is "one of their favorite subjects" for them.

Almost $94 \%$ of boys and 55\% of girls answered yes to the question "Would you like more physical education lessons at school?". 30\% of girls and $6 \%$ of boys did not think about it. At the same time, $82 \%$ of boys said they were satisfied, $15 \%$ said "not very good", $3 \%$ did not answer the question: "Are you satisfied with the physical education lessons at your school?" girls' survey data are slightly different: $75 \%$ are satisfied, $10 \%$ of respondents said they were "not satisfied with the lessons", $10 \%$ were "not very happy", 5\% did not answer. Interestingly, $10 \%$ of girls said that "physical education is not needed at all as a subject". We also found interest in fourth grade students in the physical education curriculum: swimming - $80 \%$, athletics - $42 \%$, gymnastics - $20 \%$, winter sports - 35\%, sports games - $88 \%$ and more.

These data make us think about the problem of health care for younger students, because physical education and sports, active motor activity - a condition for the full development of the child, the key to a healthy lifestyle. The updated results show that a large percentage of fourth-graders are passive in motor activity, they have no stable interest in physical education and sports. Physical education lessons in 4th grade (compared to grades 1-2) lose their 
priority among the preferences of children, the value attitude to physical education and sports differs from boys (boys have a more positive attitude to physical education and sports) and girls (girls manifest less interest in physical education lessons, not all are satisfied with school lessons, there are respondents who believe that physical education lessons are not needed). Usually, among the 4th grade students, the most motivated are those students who do sports outside of school. These surveys have confirmed the research of scientists that children are willing to play sports, in the process of playing they have positive emotions, formed an interest in physical education. We have noted that the interests of students in physical education begin to conflict with the current program, this is clearly seen in the example of the decline of interest in, say, gymnastics and increased interest in games and sports.

The issue of motives for physical education for students of different ages has been sufficiently studied in the scientific literature: the motives are dominated by the development of physical qualities ( $46 \%$ in boys, $21 \%$ in girls), posture improvement (respectively $7 \%$ and $10 \%$ ), desire to move (29\% and $30 \%$ ), communicate with friends ( $2 \%$ and $13 \%)$, get grades (4\% and $13 \%$ ), avoid teacher troubles (12\% and 15\%) (Fizychne vykhovannia, 2014).

We trace some contradiction regarding, on the one hand, the understanding of the students of the 4th class of the importance of physical education and sports for physical development of the individual, health saving, physical activity, on the other hand, such interest is not, first, sustainable, second, it is declarative and situational in nature, since after physical education at school only about $20 \%$ of children are engaged in physical activities activity in the afternoons. In addition, students' interest in physical education and sports largely depends on the content, personality of the teacher, in particular the level of his professional skill, due attention from teachers of the school to the formation of interest in the physical activity of students, facilities, equipment and more.

These and other aspects were taken into account by developing the author's method of forming a strong interest in physical education and sports in the course of extracurricular activities. Today's physical education lessons at school are not an effective means of generating young students' interest in physical education. Therefore, it was considered appropriate to create an out-of-school health environment that would maximally meet the pedagogical conditions that would provide the child with motor activity, interest in young students sports, and develop health-saving skills.

Forming a child's interest in physical education is a long process. It covers a complex structure made up of a number of interconnected components. These are the student's knowledge of physical culture and sports, health (cognitive); 
practical activity of the child in this field (activity); Valuable attitude of the student to physical training, his yearning to lead a healthy life, emotional pleasure from performing physical exercises, physical activity, sports, active recreation (value), etc. The school does not pay much attention to the cognitive and value components as our observations have shown. In our opinion, taking into account these components provides for the formation of sustainable interest of younger students. Therefore, in our program of formation of sustainable interest in physical culture these components are actualized.

The program has been implemented since 2017 at the University of the Gifted Child [UGC] (Universytet obdarovanoi dytyny [UOD], 2019), where was a favorable environment for creating a strong interest in physical education and sports has been created: for the third year in a row, Ivano-Frankivsk students participate in this project. Well-proven Olympic Reserve School (Judo, Football, etc.), Table Tennis School, School of Sports Entertainment, School of Sports Dance, School of Yourself Doctor, attended by more than 1,200 junior students during 2017-2019 (UOD, 2019). As children are actively involved in the UGC project, we will not characterize these quantitative indicators, indicating that children do not lose interest in physical education and sports, and focus more on the specific forms and educational technologies that we use in working with younger schoolchildren. First of all, let's analyze the cognitive and value components of our program of generating sustained interest in children in their physical development.

Regarding the knowledge (cognitive) component, here they sought to give children the knowledge that would encourage them to exercise in physical culture and sports. To do this in an unobtrusive way without harming motor activity, the theoretical material was organically combined with the content of the practical activity. Here are some methodical techniques. For example, during a class at the Self-Doctorate School (UOD, 2019), not only interesting things (35 minutes) were taught to teach children how to make bandages when injured with a knee while playing football or other sports games; the students were told not only about interesting events in the field of football, about famous sportsmen - immigrants from the Carpathian region, but also about how physical activity affects the mental development of the individual, the role of physical exercises in the development of forms and functions of the body, the influence of certain physical exercises that are advisable to perform daily in the morning for good functioning of the body and the like.

At the lessons of Olympic Reserve School (Judo School) talked about the traditions of physical education development in different historical epochs, informed the children about the high physical abilities of Ukrainian cossacks, scouts, their role in the fight against enemies, caring attitude to their health, 
healthy nutrition, glory, which Ukrainian cossacks have earned for their physical excellence, fitness, endurance in Europe, etc. (UOD, 2019). The children were shown fragments of the films "Cossacks" and "Ivan Syla", which starred Vasyl Virastyuk, a native of Ivano-Frankivsk city, an idol and a role model for tens of thousands of boys in Ukraine. The screening of movie fragments was accompanied by a story about V. Virastyuk - the most titled strongman of Ukraine, the holder of the titles "The Strongest Man of Ukraine" (2000, 2001, 2002, 2003, 2005), “The Strongest Man of the World” (2004), a member of the national team of Ukraine, which won the title "The Strongest Nation in the World " in 2003 and 2004. After the story, the children shared their thoughts on what it takes to become such a famous athlete as V. Virastyuk. In their evaluative judgments, younger students were unanimous: traits such as strength, agility, endurance, the desire to work on themselves, to improve their physical development, and so forth, should take a significant place. Possession of such abilities was considered as a way to self-assertion in a group of peers, class. Therefore, teachers should more often use this as an incentive for physical improvement, focusing students on the positive example of famous athletes, fellow countrymen, to emphasize that exercise is the way to the goal.

Classes were played in a play form, used an integrated approach to their conduct, maximally stimulated the motor activity of children in classes at other schools of UGC (School of Maker and Entertainment, School of Vocal, Dance School, School "Skillful Pens", School of entertainment, School of detectives, School language ecologists, eco-schools, etc.), organized outdoor activities (in the courtyard of the university, in the city park (the university is located in a park area), organized trips, quests, sports entertainment, etc. In the process of this activity sought That children under emotional satisfaction of physical training and sports, helping them find the answer to the question "What does engage in some form of sport, to perform a particular exercise?

The formation of students' understanding of the cause and effect of the influence of exercise, sports on the body, health generally contributed to the development of a sustainable interest in motor activity. This is clearly reflected in the participation of boys in the School of Dance, because usually choreography is a favorite activity for girls (UOD, 2019). Sports dance based on the elements of the hopak, the use of elements of Cossack fun, games, a story about the physical qualities of Cossacks, demonstration of individual elements of Ukrainian folk dances, etc. - all this served to interest the motor activity, the desire to improve their posture, develop not only their body, but also to form mental health (UOD, 2019). Therefore, the children studied the dance on the stage of the university during the celebrations on the occasion of the opening of 
the project "Interesting vacations". As we have seen, sports dance is an effective way of increasing the interest of younger students in motor activity. The value of choreography and music was that they became a good basis for aesthetic, moral education, generally comprehensively influenced the personality, contributed to the formation of physical, spiritual, social, moral healing of students. So, we actualized the wellness motive for physical education and sports by means of sports dance.

The wellness goal was also taken into account when competing in badminton, darts, "Funny start" games, "Cheerful choreography" in the open air, moving games, outdoor relay races (in the park, in the university courtyard), at the university stadium and so on.

Every year, starting in 2017, at the end of the Interesting Vacations project, we conducted a survey of parents and participants of the UGC, whether they were satisfied with their participation in the UGC, whether they liked physical culture and sports at the UGC, and why some of the activities offered, workshops, schools, which they liked most, what classes (schools) they would like to attend in the future, which encourages them to engage in physical culture and sports. The results of the 2019 survey are presented in the tables below. 34 girls and 30 boys participated in the survey. It should be noted that both parents and children were extremely emotionally and enthusiastically responsible for their impressions of this form of extracurricular physical education not only to us but also to numerous journalists (newspaper reporters, radio and television journalists) (UOD, 2019). All survey participants unanimously replied that they were satisfied with their participation in the UGC. Almost all the boys indicated that they enjoyed physical education and sports, four girls in the questionnaires wrote that they "never loved physical culture and sports".

The children noticed that UGC was attractive to them because they "traveled a lot", "played many sports and games", "danced sports dances", "engaged in judo", "saw their successes on the UGC page", "us we filmed, we showed in TV shows, we gave interviews", "it was very interesting to study at a real university", "we were taught by teachers and students", "we performed on a real stage", "it was a lot of fun", "we played on a board tennis", "they staged a fairy tale with the help of movements", "they learned about famous sportsmen", "work did the famous athletes come with us", "were fun starts and relay races", "prizes we got at fun starts", "often danced and played outside", "very nice and young teachers", "fun students", "fun” play badminton", "green-coated stadium", "good gymnasiums", etc.; one of the boys wrote "how sorry it is not in our school". Thus, innovative methods of training and education, their diversity, good material and technical base, highly professional teaching staff 
and other factors have provided the formation of a strong interest in the younger students to exercise in physical culture and sports, physical activity.

Among the favorite schools and workshops, the children named "Table Tennis School”, “Judo School”, School of Educational Entertainment, School of Dance, School of Acting, Eco-School and others. All survey participants indicated that they would (again for the fourth time) visit the UGC next year. Interesting were the young UGC students' answers to questions about the motivations for physical education and sports (Table 1).

Table 1 Responses of young UGC participants to the question "What motivates you to engage in physical culture and sport”? (\%)

\begin{tabular}{|l|c|c|}
\hline \multicolumn{1}{|c|}{ Motives } & Girls & Boys \\
\hline Desire to move, travel, actively rest & 92 & 100 \\
\hline Get Positive Emotions & 80 & 67 \\
\hline Formation of a Healthy Organism, Health Conservation & 78 & 86 \\
\hline $\begin{array}{l}\text { Discover something new about the physical development, } \\
\text { physical culture and sports of famous athletes-countrymen }\end{array}$ & 32 & 45 \\
\hline Exercise with Famous Athletes & 34 & 56 \\
\hline Development of physical qualities & 25 & 36 \\
\hline Improving physique & 28 & 20 \\
\hline Talking with your friends & 22 & 38 \\
\hline
\end{tabular}

As you can see, the motives for physical education and sports in children who have been attending UGC for three years are different from their peers (information is given at the beginning of the article). Dominant are such as "desire to move, travel, take a rest" (92\% in girls and 100\% in boys), "formation of a healthy personality, health" (78\% and $86 \%)$, "to receive positive emotions" (80\% and 67\%) (wellness motives), which testifies to the effectiveness of our methodology, which was based on the actualization of wellness (health saving motive) as an important factor in the formation of sustainable interest of younger students in physical education and sports. Body shape enhancement motif and sports motive are also present in the participants of the UGC. It is practically no different from the information we provided at the beginning of the article. Girls start paying attention to their figure earlier (take care of excess weight, etc.) than boys. Recreational motives ("communication with friends") are common to both boys and girls. We note the emergence of such motives in children as "learning something new about physical development, physical culture and sports" (32\% and $45 \%$ ), which we regard as a consequence of updating the cognitive component in our methodology. As we can see, the fact 
that when we involved in the training of masters of sports, well-known athletes, it was the head of the school / master class who was able to interest children in sports (34\% and 56\%). Introducing the author's technique, they focused on the child's natural need for physical activity, in the game, new impressions, positive emotions, new information, knowledge of something new, the need for physical improvement, active-positive attitude to physical culture, famous athletes, countrymen, who have succeeded in sports and more. And it gave a good result.

\section{Conclusions and recommendations}

Forming a strong interest of younger students in physical education and sports is a difficult pedagogical problem. The results of our study and the data of scientists showed that a large percentage of children are passive in motor activity, school physical education lessons lose their priority among the preferences of children, in general, among the students of the 4th grade, the most motivated to exercise are those students who exercise school, the interests of younger students in physical education come into conflict with the current school curriculum. Under the conditions of the school, young people's interest in physical development is declarative and situational in nature, since only about $20 \%$ of children engage in physical activity after school hours after physical education.

In view of this, they created the author's method of forming a sustainable interest in physical education and sports in the process of extracurricular institution, which is implemented from 2017 until today at the University of Gifted Child (UGC), which operates at the Vasyl Stefanyk Precarpathian National University. The study confirmed the hypothesis that the effectiveness of this process provides a number of conditions: the acquisition of students knowledge of physical culture and sports, health, well-known local athletes; practical activity of children; value attitudes of younger students to physical education, motivation for healthy lifestyle, emotional satisfaction from exercise, physical activity, sports, active rest; highly professional teaching staff who are well-known athletes, creative students; integrated lessons, application of innovative educational technologies, game teaching methods and more. It is proved that if the cognitive and value components are given considerable attention (which is not done in school practice), then it is possible to form a more intensive and lasting interest in children for physical culture. Health saving factor, need for active rest, physical activity, emotional value motive have become priority among motives for physical culture and sports. Quantitative data confirmed the effectiveness of the introduction of the author's method, in particular, there were no children who do not show physical and sports activity. 
The experimental work carried out over three years was effective, as evidenced by the significant changes in the results of the growth of motivation of the younger students-participants of the UGC to exercise in the physical and health activity. We believe that our pedagogical findings (practical experience of forming a strong interest among younger students in physical education and sports at the Gifted Child's University at Vasyl Stefanyk Precarpathian National University) can be fully used in any higher education institution, not only in Ukraine its boundaries, individual innovations, fruitful ideas and approaches to the organization of physical education it is expedient to apply in school practice, their creative application will serve to increase the efficiency of physical education.

\section{References}

Chen, A., \& Darst, P.W. (2001). Situational Interest in Physical Education: A Function of Learning Task Design. Research Quarterly for Exercise and Sport, 72(2), 283-289. DOI: https://doi.org/10.1080/23267224.1921.10650510

Chen, A., Darst, P.W., \& Pangrazi, R.P. (1999). What constitutes situational interest? Validating a construct in physical education. Measurement in Physical Education and Exercise Science, 3, 157-180.

Babiuk, S. (2015). Formuvannia interesu do fizychnoi kultury u molodshykh shkoliariv shliakhom vykorystannia netradytsiinykh tekhnolohii. Visnyk Kamianets-Podilskoho natsionalnoho universytetu imeni Ivana Ohiienka. Fizychne vykhovannia, sport $i$ zdorovia liudyny, 8, 62-68. Retrieved from http://nbuv.gov.ua/UJRN/ Vkpnui_fv_2015_8_10

Bergier, J., Bergier, B., \& Tsos, A. (2016). Variations in physical activity of male and female students from different countries. Iranian Journal of Public Health, 45(5), 705-707.

Bezverkhnia, H. (2003). Formuvannia motyvatsii do samovdoskonalennia uchniv zahalnoosvitnikh shkil zasobamy fizychnoi kultury i sportu: Metodychni rekomendatsii dlia vchyteliv fizychnoi kultury. Uman.

Iedynak, G., Galamandjuk, L., Kyselytsia, O., Nakonechnyi, I., Hakman, A., \& Chopik, O. (2017). Special aspects of changes in physical readiness indicators of young men with different somatotypes between 15 and 17 years of age. $J$ of Physical Education and Sport, 17(4), 2690-2696. DOI: 10.7752/jpes.2017.04311

Ivashkovskyi, V., Ostapenko, O., \& Tymchyk, M. (2014). Fizychne vykhovannia uchniv pochatkovykh klasiv u pozaklasnii roboti zahalnoosvitnikh navchalnykh zakladiv: navch.-metod. posib. Kirovohrad: Imeks-LTD.

Kravchuk, Ya., \& Voinarovska, N. (2017). Stan ta shliakhy formuvannia u shkoliariv interesu do fizychnoho vykhovannia ta sportu. Physical Education, Sports and Health Culture in Modern Society, 2, 151-155. Retrieved from https://sport.eenu.edu.ua/index.php/ sport/article/view/1408

Krutsevych, T., Vorobiov, M., \& Bezverkhnia H. (2011). Kontrol u fizychnomu vykhovanni ditei, pidlitkiv i molodi: navch. posib. Kyiv: Olimp. l-ra. 
Bilavych et al., 2020. Formation of Younger Pupils' Sustainable Interest to Take Physical Culture in Outdoor Education Institutions

The challenge of growing youth participation in sport. Retrieved from https://www.sportengland.org/media/10113/youth-insight-pack.pdf

Universytet obdarovanoi dytyny. Retrieved from https://kidsuniver.blogspot.com/.

Vilchkovskyi, E., \& Kurok O. (2008). Teoriia i metodyka fizychnoho vykhovannia ditei doshkilnoho viku: Navch. posib. Sumy: VTD. «Universytetska knyha». 